Rev. Bras. Saúde Prod. Anim., Salvador, v.17, n.2, p.149-161 abr./jun., 2016 http://www.rbspa.ufba.br ISSN 15199940

\title{
Exogenous enzymes in diets for broilers
}

\author{
Enzimas exógenas em dietas para frangos de corte
}

\author{
DALÓLIO, Felipe Santos ${ }^{1 *}$; MOREIRA, Joerley ${ }^{2}$; VAZ, Diego Pereira ${ }^{3}$; ALBINO, \\ Luiz Fernando Teixeira ${ }^{4}$; VALADARES, Leonora Ribeiro ${ }^{2}$; PIRES, Aldrin Vieira ${ }^{2}$; \\ PINHEIRO, Sandra Regina Freitas ${ }^{2}$
}

\footnotetext{
${ }^{1}$ Universidade Federal de Viçosa, Departamento de Engenharia Agrícola, Viçosa, Minas Gerais, Brasil.

${ }^{2}$ Universidade Federal dos Vales do Jequitinhonha e Mucuri, Faculdade de Ciências Agrárias, Departamento de Zootecnia, Diamantina, Minas Gerais, Brasil.

${ }^{3}$ Universidade Federal de Minas Gerais, Escola de Medicina Veterinária, Programa de Pós-Graduação em Zootecnia, Belo Horizonte, Minas Gerais, Brasil.

${ }^{4}$ Universidade Federal de Viçosa, Departamento de Zootecnia, Viçosa, Minas Gerais, Brasil.

*Endereço para correspondência: felipesantos181@hotmail.com
}

\section{SUMMARY}

The aimed of the study was to evaluate the effect of the inclusion of different levels of an enzyme complex consisting of phytase, protease, xylanase, $\beta$-glucanase, cellulase, amylase, and pectinase on the parameters of performance, carcass yield and meat quality of broilers. Six hundred broiler chicks were used, and the animals were females with one day of age, from the Cobb 500 strain, and distributed in a completely randomized design, with five levels of inclusion of the enzyme complex $(0$, $100,200,300$ and 400g/ton), and six repetitions, with twenty animals each. The weight gain, feed conversion ratio, feed intake and production viability were assessed in stages between 1 to 21,1 to 35 and 1 to 42 days of age. The carcass yield and meat quality were evaluated at 35 and 42 days of age. We evaluated the characteristics of weight loss by cooking, shear force, water holding capacity, $\mathrm{pH}$, lightness and color. The parameters of performance, carcass yield and carcass parts, and meat quality were not affected by the enzyme supplementation of diets fed to broiler chickens $(\mathrm{P}>0.05)$, except for the performance characteristics of the breast and the wings at 42 days of age $(\mathrm{P}<0.05)$.

Keywords: carcass yield, enzyme complex, meat quality, poultry, performance

\section{RESUMO}

O experimento foi realizado com o objetivo de avaliar o efeito da inclusão de diferentes níveis de um complexo enzimático composto por fitase, protease, xilanase, $\beta$ - glucanase, celulase, amilase e pectinase, em dietas à base de milho e de farelo de soja, sobre os parâmetros de desempenho, de rendimento de carcaça e de qualidade da carne de frangos de corte. Foram utilizados 600 pintos de corte, de um dia de idade, fêmeas, da linhagem Cobb 500, distribuídos em delineamento inteiramente casualizado, com cinco níveis de inclusão do complexo enzimático $(0 ; 100 ; 200 ; 300$ e 400 g/ton), e seis repetições de 20 aves cada. Foram avaliados, nas fases de 01 a 21 , de 01 a 35 e de 01 a 42 dias de idade, o ganho de peso, a conversão alimentar, o consumo de ração e a viabilidade criatória. $\mathrm{O}$ rendimento de carcaça e a qualidade da carne foram avaliados aos 35 e aos 42 dias de idade. Avaliou-se as características de perda de peso por cocção, a força de cisalhamento, a capacidade de retenção de água, o pH, a luminosidade e a cor. Os parâmetros de desempenho, de rendimento de carcaça e cortes e de qualidade da carne não foram afetados pela suplementação enzimática das dietas fornecidas aos frangos de corte $(\mathrm{P}>0,05)$, exceto para as características de rendimento de peito e de asas aos 42 dias de idade $(\mathrm{P}<0,05)$.

Palavras-chave: aves, complexo enzimático, desempenho, qualidade da carne, rendimento de carcaça 
Rev. Bras. Saúde Prod. Anim., Salvador, v.17, n.2, p.149-161 abr./jun., 2016 http://www.rbspa.ufba.br

\section{INTRODUCTION}

Poultry farming is one of the most prominent segments in the global agribusiness. This sector increased significantly after inclusion in the production chain, in the 1980s and mainly due to increasing adoption of technology in the activity. Among the mechanisms of technological, advances in nutrition with the production of food additives allowed greater assimilation of nutrients provided in the diet for broilers resulting in increased performance.

Broiler rations in Brazil are, almost entirely, formulated from two basic ingredients: corn, which is an excellent energy source, and soybean meal, which contributes with high-quality proteins and with great amino acid availability (OPALINSKI et al., 2006). However, it is known that the nutrients originated from these foods are not properly absorbed, mainly because of the presence of antinutritional factors, such as NAPs (nonamylaceous polysaccharides) and phytic acid.

Therefore, mechanisms to enhance the performance of foods given to animals were made necessary. Aiming to increase the efficiency of rations, the usage of exogenous enzymes in the feeding of broilers is gaining more space and has become a great alternative, since it enhances food digestibility, minimizing the anti-nutritional effects and promoting the productivity indexes (HOOGE et al., 2010). The use of enzyme complexes is effective, since the wide range of enzymes present in this type of product allows for greater action in different types of substrates and, or, foods utilized in the process of ration fabrication.

The SSF enzyme complex, one of the products available in the market, is showing to be effective. Basically, this type of additive uses fermentation in solid extracts conducted by specific fungi as an enzyme-production mechanism (ROBSON \& NIGAN, 2003). This results in the fabrication of a complex with, according to the substrate used in the making, a natural specific combination of enzymes and a greater spectrum of action (MOURA et al., 2012), in addition to the low final cost, which facilitates its addition to broiler rations.

In light of this, this study aimed at evaluating the performance, the carcass yield and the carcass parts, and the quality of the meat for broilers that were submitted to the diets based on corn and soybean meal with different levels of the SSF (solid state fermentation) enzyme complex.

\section{MATERIALS AND METHODS}

This experiment was conducted in the facilities of the broiler sector of the Animal Science Department of Universidade Federal dos Vales do Jequitinhonha e Mucuri (UFVJM). Six hundred broiler chicks were used, and the animals were females with one day of age, from the Cobb 500 strain. This design was completely randomized with five treatments and six replications with 20 broilers each. The treatments consisted of five inclusion level of enzyme complex $(0,100,200,300,400 \mathrm{~g} /$ ton $)$. The enzyme complex SSF is composed of seven distinct enzymes: phytase, protease, xylanase, $\beta$-glucanase, cellulase, amylase, and pectinase.

The diets were formulated according to the adaptations by Rostagno et al. (2011). The percent composition and the calculated levels of nutrients for the control diets for the initial stage (1 to 21 days of age), the growing stage (22 to 35 days of age) and the final stage (36 to 42 days of age) are presented on Table 1. 
Rev. Bras. Saúde Prod. Anim., Salvador, v.17, n.2, p.149-161 abr./jun., 2016 http://www.rbspa.ufba.br ISSN 15199940

Table 1.Percentage composition and calculated nutrient levels of experimental diets

\begin{tabular}{|c|c|c|c|}
\hline Ingredients & Initial & Growth & Final \\
\hline Corn & 61.585 & 63.990 & 67.136 \\
\hline Soybean mean & 33.413 & 30.255 & 26.619 \\
\hline Soybean oil & 1.169 & 2.636 & 3.169 \\
\hline Limestone & 0.925 & 0.816 & 0.000 \\
\hline Dicalcium phosphate & 1.490 & 1.156 & 2.040 \\
\hline Common salt & 0.456 & 0.443 & 0.418 \\
\hline L-Lysine $\mathrm{HCl}$ 99\% & 0.245 & 0.136 & 0.104 \\
\hline DL-Methionine 99\% & 0.289 & 0.209 & 0.159 \\
\hline L-Threonine 98\% & 0.073 & 0.005 & 0.000 \\
\hline Mineral supplement ${ }^{1}$ & 0.050 & 0.050 & 0.050 \\
\hline Vitamin supplement ${ }^{2}$ & 0.100 & 0.100 & 0.100 \\
\hline Salinomycin $12 \%$ & 0.055 & 0.055 & 0.055 \\
\hline Antioxidant BHT & 0.010 & 0.010 & 0.010 \\
\hline Choline chloride $60 \%$ & 0.100 & 0.100 & 0.100 \\
\hline Enzyme complex ${ }^{3}$ & 0.000 & 0.000 & 0.000 \\
\hline Inert $^{4}$ & 0.040 & 0.040 & 0.040 \\
\hline Total & 100.0 & 100.0 & 100.0 \\
\hline Metabolizable energy, $\mathrm{kcal} / \mathrm{kg}$ & 3000 & 3100 & 3150 \\
\hline Crude Protein (\%) & 20.400 & 19.000 & 17.500 \\
\hline $\mathrm{Ca}(\%)$ & 0.809 & 0.683 & 0.759 \\
\hline Non-phytate phosphorus (\%) & 0.386 & 0.319 & 0.264 \\
\hline Dig. lysine (\%) & 1.165 & 1.005 & 0.892 \\
\hline Dig. methionine (\%) & 0.559 & 0.467 & 0.403 \\
\hline Dig. methionine + cystine $(\%)$ & 0.839 & 0.733 & 0.651 \\
\hline $\mathrm{Na}(\%)$ & 0.200 & 0.195 & 0.185 \\
\hline
\end{tabular}

${ }^{1}$ Safety levels per kg of the product (Min): Folic acid 750mg; Pantothenic acid 12g; B.H.T. 1.000mg; Biotin 25mg; Niacin 35g; Vitamin A 8.000.000 UI; Vitamin B1 1.500mg; Vitamin B12 12.000mg; Vitamin B2 5.000mg; Vitamin B6 2.800mg; Vitamin D3 2.000.000 UI; Vitamin E 15.000 UI; Vitamin K3 $1.800 \mathrm{mg}$.

${ }^{2}$ Safety levels per kg of the product (Min): Copper 20g; Iron 96g; Iodine $1.400 \mathrm{mg}$; Manganese $156 \mathrm{~g}$; Selenium 360mg; Zync 110g.

${ }^{3}$ Allzyme SSF - Alltech Ind.: minimul levels of enzyme activity: phytase $300 \mathrm{UF} / \mathrm{g}$; protease $700 \mathrm{UI} / \mathrm{g}$; xylanase $100 \mathrm{UI} / \mathrm{g}$; $\beta$-glucanase $200 \mathrm{UI} / \mathrm{g}$; cellulase $40 \mathrm{UI} / \mathrm{g}$; $\alpha$ amylase $30 \mathrm{UI} / \mathrm{g}$ and pectinase $4000 \mathrm{UI} / \mathrm{g}$. ${ }^{4}$ Washed thin sand.

At 21,35 , and 42 days of age, the animals and the ration leftovers were weighted to allow for the measure the performance variables: RC (ration consumption), WG (weight gain), and
FC (feed conversion ratio). Mortality (M) was controlled daily, as well as the measurement of temperature and humidity for the inside of the house, at 9:00a.m. and at 3:00p.m. by using the 
thermohygrometer THDL - 400 Instrutherm. Later mortality data were converted in percentage, for production viability $(\mathrm{VB})(\mathrm{VB}=100 \%-\mathrm{M})$.

At 35 and at 42 days of age, two animals of each experimental group were selected by the average weight of the group $( \pm 5 \%)$ for evaluation of the performance for the carcass, breast, leg quarter, wing and abdominal fat. After eight hours of fasting, the animals were packed in boxes and transported to a room lit by artificial blue light. All the slaughtering procedures were approved by the Ethic Committee of UFVJM, process $n^{\circ} 034 / 12$.

After the evisceration, the carcass yield was obtained in relation to the body weight: $\% \mathrm{CY}=$ (carcass weight $\mathrm{x}$ 100/body weight). The yield for the breast, the leg quarter and the wing were calculated in function of the carcass weight: $\% \mathrm{BY}=$ (weight of the part $x$ 100/carcass weight). The performance for the abdominal fat was calculated in function of the body weight of the animals. For the evaluation of meat quality, cooled, skinless, boneless breast meat. The $\mathrm{pH}$ was standardized at room temperature, $25^{\circ} \mathrm{C}$, by means of a $\mathrm{pH}$ meter (Tecnopon mPA210) attached to the penetration electrode (Hanna $\mathrm{Hl}$ 8314) and introduced directly in the muscle "Pectoralis major". The method described by Hamm (1960) was utilized in order to determine the water retention capacity (WRC).

Weight loss by cooking was achieved with the methodology proposed by Cason et al. (1997). The analysis of the shear force was made by a StableMicroSystems TAXT 2 PLUS texturometer attached to a blade set $\mathrm{V}$ Wanner Bratzler probe. It was considered the force peak of the analysis, therefore determining necessary force for the cuts (OLIVEIRA et al., 2015).Color analysis was conducted with a raw meat sample, with longitudinal cuts in the breast portion made by a Minolta CR 400 colorimeter, with a CIELAB system (L*, $\mathrm{a}^{*}$ and $\mathrm{b}^{*}$ ), where $\mathrm{L}^{*}=$ luminosity, $\mathrm{a}^{*}=$ red content and $b^{*}=$ yellow content (VAN LAACK et al., 2000).

The dataset were submitted to regression analysis using software SAS (2002). Were tested the linear models and quadratic considering a 5\% significance level.

\section{RESULTS AND DISCUSSION}

The inclusion of different levels of enzyme complex in the ration of broilers did not significantly influence $(\mathrm{P}>0.05)$ the performance of broilers reared during 1 to $21 ; 1$ to 35 and 1 to 42 days of age (Table 2 ).

Similar results were found by Pinheiro et al. (2008) supplementing broiler diets in the initial stage with carbohydrases and proteases $(\mathrm{P}>0.05)$. However, Pucci et al. (2010) observed an improvement $(\mathrm{P}<0.05)$ in feed conversion ratio in broilers fed diets based on corn and soybean meal supplemented with EC (amylase, cellulase and protease). Exogenous enzymes added in broiler diets allow supplementation of endogenous enzyme production improves the assimilation of nutrients by the birds (ANGEL et al., 2011); especially in the early stage of life. However, in the supply "on top" as in this study, this effect is reduced and decreases the significant effect detection probability.

Currently in production and marketing of exogenous enzymes for feed supplementation for broiler chickens, using EC have become quite popular. For specific action allows a greater number of substrates. However, in diets with conventional ingredients such as corn and soybean meal, without reducing nutrient 
Rev. Bras. Saúde Prod. Anim., Salvador, v.17, n.2, p.149-161 abr./jun., 2016 http://www.rbspa.ufba.br ISSN 15199940

levels, its use may not become attractive. After all, in production diets for broilers, applied for integration companies, often not reduced to its nutritional recovery by increasing the breakdown of antinutritional factors of food, caused by the addition of EC. However, it has been observed in field studies that the addition of EC on the level recommended by the manufacturer, provides percentage reduction in feed conversion ratio (FERNANDES et al., 2015). As noted in this study.

Table 2. Average values for weight gain (WG), ration consumption (RC), feed conversion ratio (FC) and viability (VB), of broilers in phases $1-21 ; 1-35 ; 1$ 42 days, submitted to diets containing different levels of enzyme complex (EC)

\begin{tabular}{|c|c|c|c|c|c|c|c|}
\hline \multirow{2}{*}{ Variables } & \multicolumn{5}{|c|}{ Levels of EC Addition (g/ton) - 1 to 21days } & \multirow{2}{*}{$\begin{array}{l}\text { CV } \\
(\%)\end{array}$} & \multirow{2}{*}{$\mathrm{P}$ value } \\
\hline & 0 & 100 & 200 & 300 & 400 & & \\
\hline WG (g) & 857 & 865 & 889 & 875 & 875 & 3.17 & $0.2268^{\mathrm{ns}}$ \\
\hline $\mathrm{RC}(\mathrm{g})$ & 1203 & 1209 & 1209 & 1217 & 1209 & 3.64 & $0.7414^{\mathrm{ns}}$ \\
\hline $\mathrm{FC}(\mathrm{g} / \mathrm{g})$ & 1.40 & 1.40 & 1.36 & 1.39 & 1.38 & 2.15 & $0.2265^{\mathrm{ns}}$ \\
\hline VB $(\%)$ & 97.50 & 95.84 & 94.50 & 95.34 & 97.50 & 5.32 & $0.5614^{\mathrm{ns}}$ \\
\hline \multirow{2}{*}{ Variables } & \multicolumn{5}{|c|}{ Levels of EC Addition (g/ton) -1 to 35 days } & $\mathrm{CV}$ & \multirow{2}{*}{$\mathrm{P}$ value } \\
\hline & 0 & 100 & 200 & 300 & 400 & $(\%)$ & \\
\hline WG (g) & 2082 & 2068 & 2119 & 2115 & 2093 & 2.47 & $0.3273^{\mathrm{ns}}$ \\
\hline $\mathrm{RC}(\mathrm{g})$ & 3176 & 3161 & 3191 & 3185 & 3165 & 3.49 & $0.9845^{\mathrm{ns}}$ \\
\hline $\mathrm{FC}(\mathrm{g} / \mathrm{g})$ & 1.52 & 1.53 & 1.50 & 1.50 & 1.51 & 3.09 & $0.4502^{\mathrm{ns}}$ \\
\hline VB $(\%)$ & 95.00 & 91.67 & 91.78 & 91.06 & 95.00 & 7.20 & $0.9446^{\mathrm{ns}}$ \\
\hline \multirow{2}{*}{ Variables } & \multicolumn{5}{|c|}{ Levels of EC Addition (g/ton) - 1 to 42 days } & $\mathrm{CV}$ & \multirow{2}{*}{$\mathrm{P}$ value } \\
\hline & 0 & 100 & 200 & 300 & 400 & $(\%)$ & \\
\hline WG (g) & 2691 & 2650 & 2737 & 2676 & 2652 & 3,53 & $0,5850^{\mathrm{ns}}$ \\
\hline $\mathrm{RC}(\mathrm{g})$ & 4324 & 4332 & 4476 & 4367 & 4386 & 3,92 & $0,6952^{\mathrm{ns}}$ \\
\hline $\mathrm{FC}(\mathrm{g} / \mathrm{g})$ & 1,61 & 1,63 & 1,63 & 1,63 & 1,65 & 3,53 & $0,3243^{\mathrm{ns}}$ \\
\hline VB $(\%)$ & 91,67 & 90,00 & 90,20 & 88,57 & 94,17 & 8,43 & $0,7218^{\mathrm{ns}}$ \\
\hline
\end{tabular}

$\mathrm{CV}=$ coefficient of variation (\%); $\mathrm{P}$ value $=$ significance rate of the regression analysis; $\mathrm{ns}=\mathrm{no}$ significant $(\mathrm{P}>0.05)$.

Pereira et al. (2010) also did not observed significant effect on weight gain and on feed conversion ratio after using EC (protease, amylase and xylanase) in diets for broilers in the stage between days 1 to 35. Nonetheless, Leite et al. (2012) by using the SSF EC in the ration based on millet and soybean meal in comparison with sorghum, observed the beneficial effect $(\mathrm{P}<0.05)$ of the inclusion of $\mathrm{EC}$ on parameters of performance. Montanhini Neto et al. (2013) observed that the additional a multienzyme complex in broiler diets formulated with nonconventional food, there was increased activity and immunity of the intestinal mucosa intestinal cells. Thus, it is possible to infer that the action of enzyme complexes becomes more effective in diets with unconventional food.

Broilers in the stage between days 1 to 35 are under development and have a complete digestive and absorption systems. However, there is a greater time of contact between the enzyme and the foods, which may lead to an enhancement in performance. De Basílio \& Gerig (2011), following this line of reasoning, found a reduction on ration consumption and enhancement in feed conversion ratio $(\mathrm{P}<0.01)$ for broilers in the stage between 1 to 35 days, by evaluating the time of 
contact between SSF EC and the ration provided. This is because the authors have used diets with reduced nutrient levels, which was not done in this study. Proving this fact, Barbosa et al. (2012) observed a similar effect on weight gain and feed conversion in broilers (1-42 days) fed diets with and without reducing nutrient levels, supplemented with EC (phytase, amylase, xylanase and protease).

The results observed between days 1 to 42 confirm those found by Leite et al. (2011), who did not verify any effects of SSF EC supplementation in diets based on sorghum and soybean meal in the "on top" form (disregarding the advantages of EC in the nutritional matrix for the formulation of diets). After the pre-initial life stage of broilers, specially, the enzyme mechanisms are already established. Thus, it is possible to observe a better nutritional performance after the first week of life. This occurs when broilers are fed with rations that meet their nutritional needs, with enzyme supplementation and provided ad libitum, making it difficult to quantify the direct effect of the enzyme on the animal performance (MOURA et al., 2012). Furthermore, according to Olukosi et al. (2007) corn and soybean meal do not have a great contribution to the increase of the viscosity of diets for animals with a gastrointestinal tract in good physiological condition. Hence, there is greater possibility of action of EC in diets formulated with non-conventional foods with higher fiber content and higher presence of anti-nutritional factors, with better proliferative capacity of the crypts and villi height (LORENA-REZENDE et al., 2012; MONTANHINI NETO et al., 2012).

In turn, Bentea et al. (2010), after using SSF EC $200 \mathrm{~g} /$ ton + selenium $300 \mathrm{~g} / \mathrm{ton}$, observed significant enhancements on weight gain and feed conversion ratio
$(\mathrm{P}<0.05)$, increasing total body weight by up to $19.07 \%$ and food conversion by up to $15.35 \%$, considering the total period. Even if this study did not observe any significant effect on the animal performance, percentage increments of $1.71 \%$ in weight gain and of $1.23 \%$ in feed conversion ratio were observed for the period between 1 to 42 days of age. It is important to notice that the progress on the productive chain as a whole may not be significant and allow for an increase in profitability.

There was no significant effect $(\mathrm{P}>0.05)$ of the inclusion of different EC SSF on the parameters of carcass yield and meat quality of broilers with 35 days of age. However, this study verified a significant effect $(\mathrm{P}<0.05)$ for breast yield and wing yield at 42 days for broilers fed with diets supplemented with SSF EC (Table 3).

Figure 1 and 2 schematically represent the significant effects of the inclusion of $\mathrm{EC}$ in broiler diets at 42 days, for the breast and wings yields, respectively. Similar results were found by SotoSalanova et al. (1996) who verified an effect $\quad(\mathrm{P}<0.05) \quad$ of enzyme supplementation in diets based on corn and soybean meal on the augmentation of the breast muscle in broilers with 42 days of age.

The greatest percentage increase, an average of $2.15 \%$ in relation to the other treatments, of the breast, with the enzyme levels recommended by the manufacturer (200g/ton), may have occurred due to the fact that this level provides a better digestibility of the ingredients and, therefore, increases the amount of nutrients available for breast growth. The breast becomes the most important section, it represents about $50 \%$ of the total protein of the chicken (ALMEIDA et al., 2002); with increased ability to produce derivatives of chicken feed. These results to poultry industry are very important because 
Rev. Bras. Saúde Prod. Anim., Salvador, v.17, n.2, p.149-161 abr./jun., 2016 http://www.rbspa.ufba.br ISSN 15199940

there is a tendency to sell cuts over the whole carcass due to increase in value aggregate. For every other level over the recommended value for EC, this response may have not existed due to the lack of substrate available after the addition of an amount of enzymes greater than the recommended number without considering the nutritional energy matrix and, or, the diet proteins.

Table 3. Average values for carcass yield (CY), breast yield (BY), wing yield (WY), leg quarter yield (LQY) and fat yield (FY), of broilers of 35 and 42 days of age, submitted to diets containing different levels of enzyme complex (EC)

\begin{tabular}{|c|c|c|c|c|c|c|c|}
\hline \multirow{2}{*}{ Variables } & \multicolumn{5}{|c|}{ Levels of EC addition ( $\mathrm{g} / \mathrm{ton})-35$ days } & \multirow{2}{*}{$\begin{array}{l}\text { CV } \\
(\%)\end{array}$} & \multirow{2}{*}{$P$ value } \\
\hline & 0 & 100 & 200 & 300 & 400 & & \\
\hline $\mathrm{CY}$ & 73.54 & 74.32 & 74.17 & 74.04 & 73.6 & 1.39 & $0.9344^{\mathrm{ns}}$ \\
\hline BY & 38.61 & 38.07 & 38.12 & 38.71 & 38.67 & 3.57 & $0.6733^{\mathrm{ns}}$ \\
\hline WY & 10.47 & 10.34 & 10.18 & 10.32 & 10.43 & 4.36 & $0.8695^{\mathrm{ns}}$ \\
\hline LQY & 27.04 & 26.57 & 26.60 & 26.88 & 26.53 & 2.45 & $0.4168^{\mathrm{ns}}$ \\
\hline FY & 1.88 & 1.62 & 1.41 & 1.70 & 1.67 & 27.36 & $0.5648^{\mathrm{ns}}$ \\
\hline \multirow{2}{*}{ Variables } & \multicolumn{5}{|c|}{ Levels of EC addition (g/ton) - 42 days } & $\mathrm{CV}$ & \multirow{2}{*}{$\mathrm{P}$ value } \\
\hline & 0 & 100 & 200 & 300 & 400 & $(\%)$ & \\
\hline CY & 74.06 & 73.25 & 73.21 & 72.70 & 75.36 & 2.61 & $0.2838^{\mathrm{ns}}$ \\
\hline BY & 40.05 & 40.11 & 40.41 & 39.73 & 38.24 & 3.65 & $0.0417^{\mathrm{L}}$ \\
\hline WY & 9.73 & 10.44 & 10.22 & 10.84 & 10.43 & 5.28 & $0.0228^{\mathrm{L}}$ \\
\hline LQY & 26.46 & 26.74 & 26.85 & 27.21 & 27.50 & 6.62 & $0.3225^{\mathrm{ns}}$ \\
\hline FY & 1.76 & 1.67 & 1.64 & 1.98 & 1.58 & 26.31 & $0.8591^{\mathrm{ns}}$ \\
\hline
\end{tabular}

$\mathrm{CV}=$ coefficient of variation $(\%) ; \mathrm{P}$ value $=$ significance rate of the regression analysis; ns $=$ no significant $(\mathrm{P}>0.05) ; \mathrm{L}=$ linear regression $(\mathrm{P}<0.05)$.

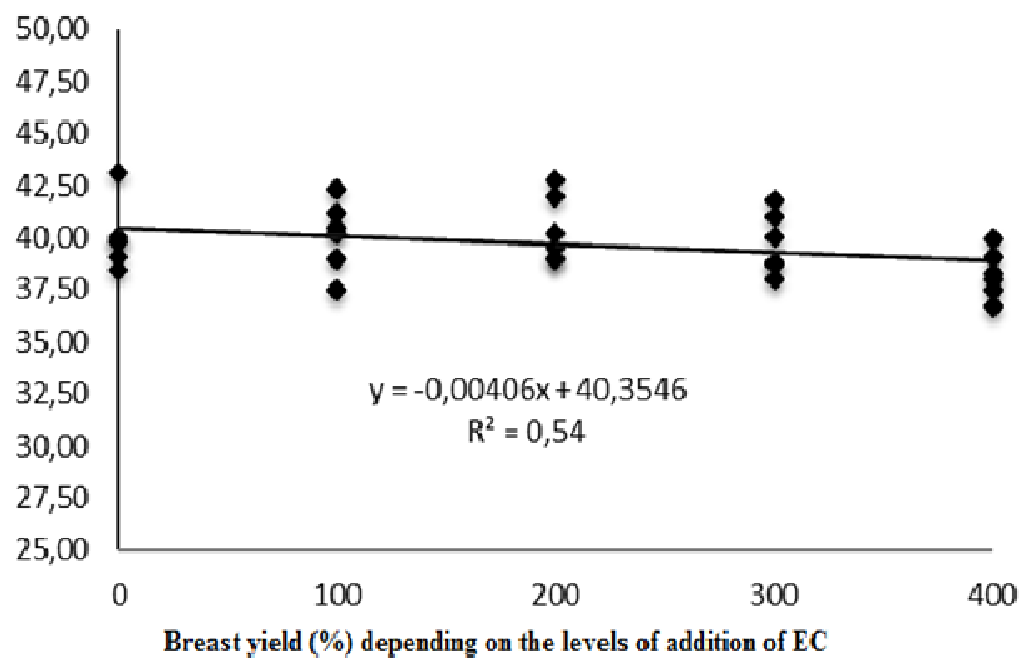

Figure 1. Breast yield (\%) of broilers reared at 42 days fed diets supplemented with different levels of EC $(0$, $100,200,300$ and $400 \mathrm{~g} /$ ton) 
Rev. Bras. Saúde Prod. Anim., Salvador, v.17, n.2, p.149-161 abr./jun., 2016 http://www.rbspa.ufba.br

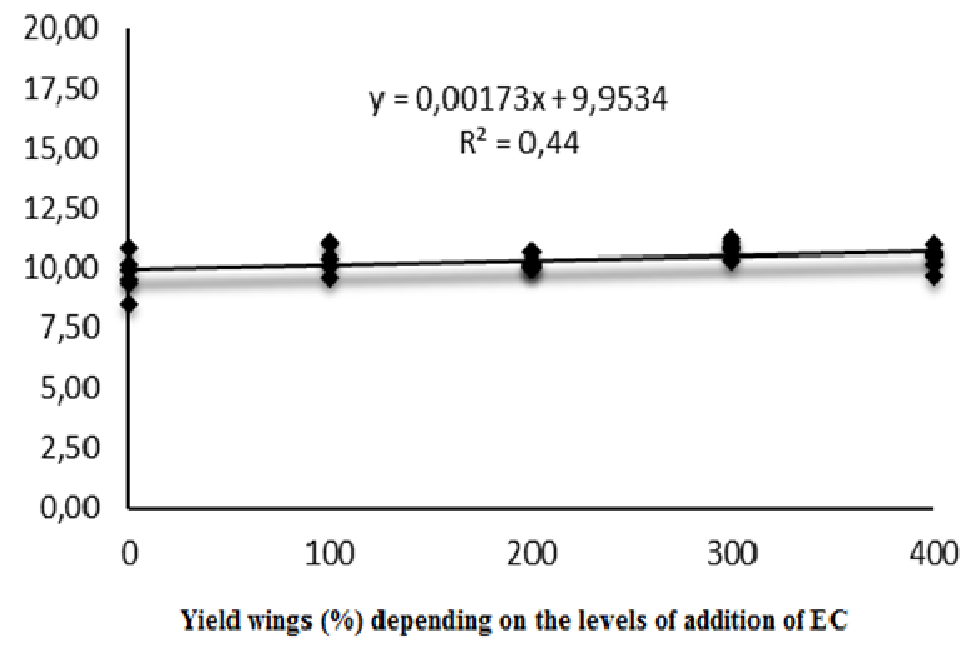

Figure 2. Wings yield (\%) of broilers reared at 42 days fed diets supplemented with different levels of EC $(0,100,200,300$ and $400 \mathrm{~g} /$ ton $)$

It may also be due to the low fiber content present in low viscosity diets (SOTOSALANOVA et al., 1996). Therefore, regarding the rations with $\mathrm{EC}$ supplementation in the "on top" form, it is verified that the enzyme does not produce any beneficial effects above the recommended level, which happens due to the quality of the foods used in the formulation and to the meeting of the nutritional demands of the broilers.

Silveira et al. (2010), after studying the use of SSF EC in pelleted diets by analyzing contrasts, were able to verify an effect $(\mathrm{P}<0.05)$ on the performance of the leg quarter at 21 days of age, with a percentage reduction of $25 \%$ in relation to the control diet. However, no significance was observed for the performance of the breast $(\mathrm{P}>0.05)$. Cardoso et al. (2011) also did not verify any differences $(\mathrm{P}>0.05)$ on carcass yield for broilers with 42 days of age. Regarding abdominal fat, Souza et al. (2008) observed an increase in the carcass of broilers at 42 days of age. According to Kessler et al. (2000) the most efficient way to avoid fat excess in the carcass is the approximation between energy and protein levels. This fact can be explained by the increase in food digestibility to the level recommended for the addition of the EC, which overestimates the energy values of the ration. Thus, with the energy excess, there is the possibility of greater accumulation of abdominal fat, a fact that was not identified within this study.

Broiler meat, according to Petracci \& Baéza (2011), has the following as its main intrinsic attributes: appearance, texture, succulence, flavor, and functionality; coloring is the most important factor that affects the choice of consumers. They also state that the $\mathrm{pH}$ is closely related to all the factors that affect meat quality, although this effect is complex. This complexity is due to the many reaction associated with the heme factor, which depends on $\mathrm{pH}$ (WERNER et al., 2009). Since all the factors and meat quality parameters will depend directly from the management conditions, lineage, and especially the type of feed provided to the birds (NEVES et al., 2014).

The addition of exogenous enzymes in the feed of broilers, probably, improves nutrient digestibility efficiency and promotes greater carcass yield and meat 
Rev. Bras. Saúde Prod. Anim., Salvador, v.17, n.2, p.149-161 abr./jun., 2016 http://www.rbspa.ufba.br ISSN 15199940

deposition (ALLOUCHE et al., 2015). The increase in protein deposition may change the type and shape of fiber to be deposited on the substrate, and may therefore change the meat quality parameters (FATUFE et al., 2004); especially abdominal fat increased efficiency in the use of nutrients. Therefore, the inclusion of the SSF EC did not influence $(\mathrm{P}>0.05)$ the parameters of meat quality of broilers with 35 and 42 days of age (Table 4).

Table 4. Average values for weight loss by cooking (WLC), shear force (SF), water retention capacity (WRC), hydrogenionic potential $(\mathrm{pH})$, luminosity $\left(\mathrm{L}^{*}\right)$, red content ( $\mathrm{a}^{*}$ ) and yellow content $\left(\mathrm{b}^{*}\right)$ of the breast of broilers with 35 and 42 days of age, submitted to diets containing different levels of enzyme complex (EC)

\begin{tabular}{|c|c|c|c|c|c|c|c|}
\hline \multirow{2}{*}{ Variables } & \multicolumn{5}{|c|}{ Levels of EC addition (g/ton) - 35 days } & \multirow{2}{*}{$\begin{array}{l}\text { CV } \\
(\%)\end{array}$} & \multirow{2}{*}{$\mathrm{P}$ value } \\
\hline & 0 & 100 & 200 & 300 & 400 & & \\
\hline WLC (\%) & 29.29 & 28.76 & 29.51 & 29.32 & 29.23 & 10.99 & $0.9137^{\mathrm{ns}}$ \\
\hline $\mathrm{SF}\left(\mathrm{kgf.cm}{ }^{-2}\right)$ & 2.53 & 2.65 & 2.97 & 2.26 & 2.77 & 25.75 & $0.9200^{\mathrm{ns}}$ \\
\hline WRC $(\%)$ & 45.61 & 42.24 & 46.13 & 43.35 & 44.68 & 10.40 & $0.9009^{\mathrm{ns}}$ \\
\hline $\mathrm{pH}$ & 5.92 & 5.87 & 5.88 & 5.83 & 5.85 & 1.63 & $0.1585^{\mathrm{ns}}$ \\
\hline $\mathrm{L}^{*}$ & 48.11 & 48.43 & 50.47 & 49.3 & 51.21 & 5.95 & $0.0658^{\mathrm{ns}}$ \\
\hline$a^{*}$ & 3.84 & 3.08 & 3.77 & 3.16 & 3.76 & 20.21 & $0.9364^{\mathrm{ns}}$ \\
\hline$b^{*}$ & 5.03 & 5.32 & 5.73 & 5.32 & 5.39 & 22.92 & $0.6409^{\mathrm{ns}}$ \\
\hline \multirow{2}{*}{ Variables } & \multicolumn{5}{|c|}{ Levels of EC addition (g/ton) - 42 days } & $\mathrm{CV}$ & \multirow{2}{*}{$P$ value } \\
\hline & 0 & 100 & 200 & 300 & 400 & $(\%)$ & \\
\hline WLC (\%) & 30.54 & 26.40 & 29.54 & 31.48 & 26.03 & 16.79 & $0.5510^{\mathrm{ns}}$ \\
\hline $\mathrm{SF}\left(\mathrm{kgf.cm}{ }^{-2}\right)$ & 3.16 & 3.07 & 3.33 & 2.45 & 3.20 & 18.61 & $0.4969^{\mathrm{ns}}$ \\
\hline WRC $(\%)$ & 44.98 & 47.13 & 44.2 & 48.01 & 46.71 & 10.51 & $0.4850^{\mathrm{ns}}$ \\
\hline $\mathrm{pH}$ & 5.72 & 5.67 & 5.68 & 5.69 & 5.71 & 0.93 & $0.8317^{\mathrm{ns}}$ \\
\hline $\mathrm{L}^{*}$ & 49.79 & 49.37 & 50.40 & 49.6 & 48.22 & 5.23 & $0.3751^{\mathrm{ns}}$ \\
\hline$a^{*}$ & 3.16 & 3.07 & 3.33 & 2.45 & 3.20 & 21.78 & $0.3226^{\mathrm{ns}}$ \\
\hline$b^{*}$ & 7.66 & 6.72 & 7.67 & 7.22 & 7.82 & 15.10 & $0.5782^{\mathrm{ns}}$ \\
\hline
\end{tabular}

$\mathrm{CV}=$ coefficient of variation $(\%) ; \mathrm{P}$ value $=$ significance rate of the regression analysis; ns $=$ no significant $(\mathrm{P}>0.05)$.

According to Werner et al. (2009) the addition of enzymes does not affect quality parameters of the meat; they are interconnected with color and $\mathrm{pH}$, which are mainly hampered by the loss of exudate and temperature pitches. Zakaria et al. (2010) while working with diets based on corn and soybean meal supplemented with the SSF EC, also did not observe any effects $(\mathrm{P}>0.05)$ regarding the parameters $\mathrm{pH}$, WLC, WRC, color and luminosity in carcass for broilers at 42 days of age.

The poultry industry is characterized by high production volume, mainly by the broiler industry. In this sense, the productive reality the use of exogenous enzymes can provide obtaining percentage gains in carcass characteristics, making it an extremely attractive alternative from an economic point of view (RAVINDRAN, 2013). However, there greater need for studies that point advantages when it reduces the nutritional value of diets and also those that correlate the cost-benefit of the inclusion of EC in diets for broilers. All these factors combined with the proper management of poultry production will allow consecutive increases in productivity and expansion of Brazilian agribusiness.

Given the above, based on the results 
Rev. Bras. Saúde Prod. Anim., Salvador, v.17, n.2, p.149-161 abr./jun., 2016 http://www.rbspa.ufba.br ISSN 15199940

obtained in this study, it can be inferred that the inclusion of the SSF enzyme complex in diets based on corn and soybean meal for broilers, in the levels recommended by the manufacturer, $200 \mathrm{~g} / \mathrm{ton}$, enhanced the efficiency of the breast and the wing yields at 42 days and did not significantly influence the performance, the carcass yield and the quality of the meat.

\section{ACKOWLEDGEMENTS}

The authors thank CAPES, CNPq and FAPEMIG, for funding the project and the granting of scholarships.

\section{REFERENCES}

ALLOUCHE, L.; MADANI, T.; HAMOUDA, A.; BOUCHERIT, M.R.; TALEB, H.; SAMAH, O.; RAHAMANI, K.; TOUABATI, A. Effect of addition of exogenous enzymes in hypocaloric diet in broiler chicken on performance, biochemical parameters and meat characteristics. Biotechnology in Animal Husbandry, v.31, n.4, p.551-565, 2015.

ALMEIDA, I.C.L.; MENDES, A.A.; GARCIA, R.G.; TAKITA, T.S.; MOREIRA, J.; GARCIA, E.A. Efeito do nível de lisina da dieta e do sexo sobre o desempenho e rendimento de carcaça de frangos de corte. Revista Brasileira de Ciência Avícola, v.4, n.1, p.1-8, 2002.

ANGEL, C.R.; SAYLOR, W.; VIEIRA, S.L.; WARD, N. Effects of a monocomponent protease on performance and protein utilization in 7- to 22-day-old broiler chickens. Poultry Science, v.90, n.10, p.2281-2286, 2011.
BARBOSA, N.A.A.; SAKOMURA, N.K.; BONATO, M.A.; HAUSHILD, L.; OVIEDO-RONDON, E. Enzimas exógenas em dietas de frangos de corte: desempenho. Ciência Rural, v.42, n.8, p.1497-1502, 2012.

BENTEA, M.; SARA, A.; PANTǍ, L.; CLAPA, L. The effects of enzymatic complex allzyme SSF and organic selenium on some growth and consumption indices of broiler turkey.

Animal Science and Biotechnologies, v.43, n.1, p.9-14, 2010.

CARDOSO, D.M.; MACIEL, M.P.; PASSOS, D.P.; SILVA, F.V.; REIS, S.T.; AIURA, F.S. Efeito do uso de complexo enzimático em rações para frangos de corte. Archivos de

Zootecnia, v.60, n.232, p.1053-1064, 2011.

CASON, J.A.; LYON, C.E.; PAPA, C.M. Effect of muscle opposition during rigor on development of broiler breast meat tenderness. Poultry Science, v.76, n.5, p.785-787, 1997.

DE BASÍLIO, V.; GERIG, C.F. The effect of contact time between exogenous enzyme and broiler starter feed. In: LATIN AMERICAN POULTRY CONGRESS, 22., 2011, Maracy, Venezuela,. Anais... Maracy, Venezuela, 2011.

FATUFE, A.A.; TIMMLER, R.; RODEHUTSCORD, M. Response to lysine intake in composition of body weight gain and efficiency of lysine utilization of growing male chickens from two genotypes. Poultry Science, v.83, n.8, p.1314-1324, 2004. 
Rev. Bras. Saúde Prod. Anim., Salvador, v.17, n.2, p.149-161 abr./jun., 2016 http://www.rbspa.ufba.br ISSN 15199940

FERNANDES, J.I.M.; BORTOLUZZI, C.; BURIN JUNIOR, A.M.; RORIG, A.; PERINI, R.; CRISTO, A.B. Effect of different enzymatic supplements in diets of broilers reared at high stocking density. Journal of Veterinary Medicine and Research, v.2, n.1, p.1016-1020, 2015.

HAMM, R. Biochemistry or meat hydratation: advances in food research. Cleveland, v.10, n.2, p.335-443, 1960.

HOOGE, D.M.; PIERCE, J.L.; McBRIDE, K.W.; RIGOLIN, P.J. Metaanalysis of broiler chicken trials using diets with or without allzyme SSF enzyme complex. International Journal of Poultry Science, v.9, n.9, p.819-823, 2010.

KESSLER, A.M.; SNIZER JUNIOR, P.N.; BRUGALLI, I. Manipulação da quantidade de gordura na carcaça de frangos. In: CONFERÊNCIA APINCO DE CIÊNCIA E TECNOLOGIA AVÍCOLAS, 2000, Campinas. Anais... São Paulo: FACTA, 2000. v.2, p.107133.

LEITE, J.L.B.; LEANDRO, N.S.M.; STRINGHINI, J.H.; CAFÉ, M.B.; GOMES, N.A.; JARDIM FILHO, R.M. Desempenho de frangos de corte e digestibilidade de rações com sorgo ou milheto e complexo enzimático. Pesquisa Agropecuária Brasileira, v.46, n.3, p.280-286, 2011.

LEITE, P.R.S.C.; LEANDRO, N.S.M.; STRINGHINI, J.H.; SOUZA, E.S.; CAFÉ, M.B.; CARVALHO, F.B.; ANDRADE, M.A. Microbiota intestinal e desempenho de frangos alimentados com rações elaboradas com sorgo ou milheto e complexo enzimático. Arquivo Brasileiro de Medicina Veterinária e Zootecnia, v.64, n.6, p.1673-1681, 2012.
LORENA-REZENDE, I.M.B.; DUTRA

JÚNIOR, W.M.; PALHARES, L.O.;

LUDKE, M.C.M.M.; RABELLO, C.B.V. Digestibility of the cottonseed meal with or without addition of protease and phytase enzymes in swine diet. Acta Sicientiarum. Animal Sciences, v.34, n.3, p.259-265, 2012.

MONTANHINI NETO, R.; CECCANTINI, M.L.; FERNANDES, J.I.M. Productive performance, intestinal morphology and carcass yield of broilers fed conventional and alternative diets containing commercial enzymatic complex. International Journal of Poultry Science, v.11, n.8, p.505-516, 2012.

MONTANHINI NETO, R.; CECCANTINI, M.L.; FERNANDES, J.I.M. Immune response of broilers fed conventional and alternative diets containing multi-ezyme complex. Revista Brasileira de Ciência Avícola, v.15, n.3, p.223-231, 2013.

MOURA, G.S.; LANNA, E.A.T.; FILER, K.; FALKOSKI, D.L.; DONZELE, J.L.; OLIVEIRA, M.G.A.; REZENDE, S.T. Effects of enzyme complex SSF (solid state fermentation) in pellet diets for Nile tilapia. Revista Brasileira de Zootecnia, v.41, n.10, p.2139-2143, 2012.

NEVES, D.P.; BANHAZI, T.M.; NÄÄS, I.A. Feeding behaviour of broiler chickens: a review on the biochemical characteristics. Revista Brasileira de Ciência Avícola, v.16, n.2, p.1-16, 2014.

OLIVEIRA, F.R.; BOARI, C.A.; PIRES, A.V.; MOGNATO, J.C.; CARVALHO, R.M.S.; SANTOS JÚNIOR, M.A.; MATTIOLI, C.C. Jejum alimentar e qualidade de carne de frango de corte tipo caipira. Revista Brasileira de Saúde e Produção Animal [online], v.16, n.3, p.667-677, 2015. 
Rev. Bras. Saúde Prod. Anim., Salvador, v.17, n.2, p.149-161 abr./jun., 2016 http://www.rbspa.ufba.br ISSN 15199940

OLUKOSI, O.A.; COWIESON, A.J.; ADEOLA, O. Age-related influence of a cocktail of xylanase, amylase, and protease or phytase individually or in combination in broilers. Poultry Science, v.86, n.1, p.77-86, 2007.

OPALINSKI, M.; MAIORKA, A.; CUNHA, F.; SILVA, E.C.M.; BORGES, S.A. Adição de níveis crescentes de complexo enzimático em rações com soja integral desativada para frangos de corte. Archives of

Veterinary Science, v.11, n.3, p.31-35, 2006.

PEREIRA, P.W.Z.; MENTEN, J.F.M.; RACANICCI, A.M.C.; TRALDI, A.B.; SILVA, C.S.; RIZZO, P.V. Avaliação de complexo enzimático e betaína natural em rações para frangos de corte criados em aviário comercial. Revista Brasileira de Zootecnia, v.39, n.10, p.2230-2236, 2010.

PETRACCI, M.; E, BAÉZA.

Harmonization of methodologies for the assessment of poultry meat quality features. World's Poultry Science Journal, v.67, n.1, p.137-151, 2011.

PINHEIRO, C.C.; REGO, J.C.C.; RAMOS, T.A.; SILVA, B.K.R.; WARPECHOWSKI, M.B.

Digestibilidade dos nutrientes e desempenho de frangos de corte consumindo dietas formuladas com diferentes níveis de fibra e suplementadas com enzimas exógenas. Ciência Animal Brasileira, v.9, n.4, p.984-996, 2008.

PUCCI, L.E.A.; RODRIGUES, P.B.; BERTECHINI, A.G.; NASCIMENTO, G.A.J.; LIMA, R.R.; SILVA, L.R. Forma física, suplementação enzimática e nível nutricional de rações para frangos de corte na fase inicial: desempenho e digestibilidade dos nutrientes. Revista Brasileira de

Zootecnia, v.39, n.6, p.1271-1279, 2010.

RAVINDRAN, V. Feed enzymes: The science, practice, and metabolic realities. Journal Applied of Poultry Research, v.22, n.3, p.628-636, 2013.

ROBSON, T.; NIGAN, P. Biorector design for protein enrichment of agricultural residues by solid state fermentation. Biochemical

Engineering Journal, v.13, n.2, p.107203, 2003.

ROSTAGNO, H.S.; ALBINO, L.F.T.; DONZELE, J.L.; GOMES, P.C.; DONZELE, R.F.M.O.; LOPES, D.C.; FERREIRA, A.S.; BARRETO, S.L.T.; EUCLIDES, R.F. Tabela brasileira para aves e suínos: composição de alimentos e exigências nutricionais. 3.ed. Viçosa, MG: UFV, 2011. 252 p.

SAS. Statistical Analysis System. User`s Guide: Statistics. Cary, NC: SAS Institute Inc., 2002.

SILVEIRA, M.H.D; ZANUSSO, J.T.; ROSSI, P.; RUTZ, F.; ANCIUTI, M.A.; ZAUK, N.F.; RIBEIRO, C.L.G.; BRUM, P.A.R.; NUNES, J.K. Efeito da peletização em dietas contendo complexo enzimático para frangos de corte. Ciencia Animal Brasileira, v.11, n.2, p.326-333, 2010.

SOTO-SALANOVA, M.F.; GARCIA, O.; GRAHAM, H. Uso de enzimas em dietas de milho e soja para frangos de corte. In: CONFERÊNCIA APINCO'96 DE CIÊNCIA E TECNOLOGIA AVÍCOLAS, 1996, Curitiba, Paraná. Anais... Curitiba, 1996. p.71-76. 
Rev. Bras. Saúde Prod. Anim., Salvador, v.17, n.2, p.149-161 abr./jun., 2016 http://www.rbspa.ufba.br

SOUZA, R.M.; BERTECHINI, A.G.;

SOUSA, R.V.; RODRIGUES, P.B.;

CARVALHO, J.C.C.; BRITO, J.A.G.

Efeito da suplementação enzimática e

da forma física da ração sobre o

desempenho e as características de

carcaça de frangos de corte. Revista

Ciência e Agrotecnologia, v.32, n.2, p.584-590, 2008.

VAN LAACK, R.L.J.M.; LIU, C.H.; SMITH, M.O.; LOVEDAY, H.D.

Characteristics of pale, soft, exudative broiler breast meat. Poultry Science, v.79, n.7, p.1057-1061, 2000.

WERNER, C.; JANISCH, S.;

KUEMBET, U.; WICKE, M.

Comparative study of the quality of broiler and turkey meat. British

Poultry Science, v.50, n.3, p.318-324, 2009.

ZAKARIA, H.; JALAL, M.A.R.; ABU ISHMAIS, M.A. The influence of supplemental multi-enzymes feed additive on the performance, carcass characteristics, and meat quality traits or broiler chickens. International Journal of Poultry Science, v.9, n.2, p.126-133, 2010 .

Data de recebimento: $13 / 11 / 2014$

Data de aprovação: 10/05/2016 